\title{
Adoption of Soil and Water Conservation Measures, its Impact on Yield and Technical Efficiency: Insights from Drought Prone Areas of the Karnataka, India
}

\author{
Suresh Kumar ${ }^{1}$, D R Singh ${ }^{2}$, N Singh ${ }^{3}$, and G Jha ${ }^{2}$ \\ ${ }^{1}$ ICAR-Indian Agriculture Research Institute, New Delhi-110012 \\ ${ }^{2}$ ICAR-Indian Agriculture Research Institute \\ ${ }^{3}$ ICAR-National Institute of Agricultural Economics and Policy Research Library
}

May 26, 2020

\begin{abstract}
This paper examines drivers of adoption of soil and water conservation measure, and its impact on yield and technical efficiency of maize cultivation using plot level data from drought prone area of Karnataka, India. To account for selection bias from both observable and unobservable factors, an endogenous switching regression model is employed to estimate the impact of technology on yield and technical inefficiency, which is estimated data envelope analysis-meta-frontier approach. Results reveal that adoption of soil and water conservation measure i.e. bunding leads to significant increase yield of maize by $30 \%$ and reduces technical inefficiency by $28 \%$. Further, results reveal that farmers' access to credit, extension services, access to credit and extension services not only has positive influence on the adoption of soil and water conservation measures, but also associated with higher technical efficiency. Overall, results point to need further scaling of soil and water conservation measures for greater adoption, particularly in drought prone areas. The paper concludes that policymakers and development organizations should consider soil and water conservation as main strategy improve the crop productivity, and thereby the livelihoods, particularly of resource poor farmers.
\end{abstract}

\section{Hosted file}

LDD6_text.docx available at https://authorea.com/users/326138/articles/454353-adoptionof-soil-and-water-conservation-measures-its-impact-on-yield-and-technical-efficiencyinsights-from-drought-prone-areas-of-the-karnataka-india 